\title{
Uterine Corpus Carcinoma Clinical Distant Metastasis TNM Finding v7
}

National Cancer Institute

\section{Source}

National Cancer Institute. Uterine Corpus Carcinoma Clinical Distant Metastasis TNM

Finding v7. NCI Thesaurus. Code C89576.

A clinical finding about one or more characteristics of uterine corpus carcinoma, following the rules of the TNM AJCC v7 classification system as they pertain to distant metastases. (from AJCC 7th Ed.) 